\title{
Human Rights and Religion: Islam in Perspective
} Muhammed Hamid Muhammed ${ }^{1}$

Rights and Religion: Islam in Perspective

\section{Abstract}

Though human rights exist in every religion as a concept, contemporary human rights movements blame religions for their resistance. Meanwhile, religious narratives are needed to ground normative foundations of human rights. Islam is one of the religions that give a prominent place for human rights. It recognized the dignity and the sanctity of human life long before the modern human rights movements were incepted. However, there are still confusion and misconceptions regarding the place of human rights in Islam. Therefore, the primary purpose of this paper is to show how human rights are intrinsic values of Islam and to clarify existing confusions and misconceptions. Henceforth, the paper highlighted the relationship between human rights and religion; the debates, misconceptions, and confusions surrounding human rights in Islam; and examples of fundamental rights in Islam.

Keywords: human rights, religion, the West, Islam, Sharia

\author{
İslam Perspektifinde İnsan Hakları ve Din \\ $\ddot{O} z$
}

İnsan hakları her dinde bir kavram olarak var olsa da, çağdaş insan hakları hareketleri direnişlerinden dolayı dinleri suçlamaktadır. Bu arada, insan haklarının normatif temellerini ortaya koymak için dini anlatılara ihtiyaç vardır. İslam, insan hakları konusunda öne çıkan dinlerden biridir. Modern insan hakları hareketleri kabul edilmeden çok önce İslam, insan yaşamının onurunu ve kutsallığını kabul etmiştir. Bununla birlikte, insan haklarının İslam'daki yeri konusunda hala kafa karışıklıkları ve yanlış anlamalar bulunmaktadır. Bu nedenle, bu makalenin temel amacı, insan haklarının nasıl İslam'ın içsel değerleri olduğunu göstermek ve var olan kafa karışıklıklarına ve yanlış anlamalara açıklık getirmektir. Bundan ötürü makale, insan hakları ve din arasındaki ilişkiye vurgu yapmış; İslam'da insan haklarıyla ilgili tartışmalara, yanlış anlamalara, kafa karışıklıklarına ve temel haklar örneklerine işaret etmiştir.

Anahtar Sözcükler: insan hakları, din, Batı, İslam, Şeriat

\section{Introduction}

The principles dictating modern human rights had been the doctrines of different religious creeds for a long time. Meanwhile, the contemporary human rights movement blame religions, particularly Islam, for their resistance to human rights. The distrust and dismay of the human rightist movements for religions are induced by the historical anomalies encountered. The historical development of human rights reveals that for most of human history, some religious leaders rejected what we today describe as fundamental human rights. Traditionally, most religious leaders were primarily involved in imposing their authority and enriching personal aggrandizement rather than promoting and defending their followers' rights. Unfortunately, because of this historical trajectory, the importance of religion for human rights and their mutual reinforcement had been disregarded by human rights scholars and activists. Therefore, until recently, human rights support has come more consistently from secular movements than religious groups. However, it is argued here that religions have significant substantive human rights contents that have been dictating society's political, economic, social, and cultural aspects for a long period. For instance, Jews and Christians affirm that persons have human rights because they are created in God's image (Grant, 2007). Hindus and Buddhists also recognize not only human rights but rights for animals as well. In the same token, some human rights principles are steamed with the doctrine of Islam so that; its contribution to the protraction and on-going realization of human

\footnotetext{
${ }^{1}$ Bahir Dar University, Bahir Dar, Ethiopia, email: muhammedhamid12@ gmail.com, ORCID: 0000-0002-4629-2307.
} 
rights cannot be ignored. Consequently, bridging the gap between modern human rights movements and religions, especially with Islam, will probably help the struggle for the protection, respect, and fulfillment of human rights effectively and sustainably.

\section{Defining religion}

The religion faculty is believed to be a defining feature of human personhood. It has been a part of human consciousness and culture that dignifies the human race and defines its identity. It serves as the manifestation of human diversity regarding views on the ultimate meaning of life, the existence and non-existence of a divine being, and how to attain happiness. It is imperative to briefly discuss some definitions of religion if one needs to demonstrate the interplay between religion and human rights. However, the lack of comprehensible definitions of religion's concept has made an attempt very difficult and complicated. Among the scholars in philosophy and religion, there has always been a lively debate about how religion should be understood. According to Gunn (2003), the effort to define religion is as old as the academic study of religion itself. Narrowly, it has been defined in terms of the speaker's religious beliefs and culture, excluding other cultures' religious beliefs. In other cases, very broadly, it is thought to include other areas of human thought (Connelly, 1996).

Though the polemics surrounding the definition of religion is not the central focus here, it is imperative to discuss some definitions in brief. Paul Tillich (1963) defines religion as "The state of being grasped by an ultimate concern, a concern which qualifies all other concerns as preliminary and which itself contains the answer to the question of the meaning of life." Tillich`s definition characterized religious faith as the ultimate or most conspicuous concern that humans can have, and both the divinity and the faith were part of one system of a religious panorama. Jeremy Gunn (2003) believes that religion has arisen from an attempt to represent and order beliefs, perceptions, imaginings, and actions that arise in response to the sacred and spiritual direct experience.

Kirkland (2001), cited in Jozwiak (2008), defined religion substantively in terms of the supposed content or 'substance' of religious thought and values and functionally in terms of its supposed consequences or functions within the human psyche, human society, or human culture. The substantive definition essentially concerns what religion is, while a functional definition is basically what religion does. For its integrative (substantive and functional) nature and broadness in its scope, Kirkland`s (2001) definition of religion is taken here.

Religion originates in humanity's tendency to seek to maximize the meaning and value of our life-experience by aligning that life-experience with a higher or deeper reality, with "an unseen order" that somehow transcends ordinary human existence. That alignment can serve to integrate diverse aspects of our lives (individually and collectively) and to permeate our lives with a sense of purpose and direction. The concern with establishing and maintaining a harmonious relationship with the higher/deeper reality while conducting our everyday life often generates religious values - guidelines for thought and action that often develop into a powerful cultural force. (Kirkland, 2001 cited in Jozwiak, 2008)

\section{Religion and Human Rights}

Here it is tried to cement the belief that religions form the foundation from which human rights developed. In every religion, there are normative principles that serve as the philosophical framework for human rights discourse. Describing how religious norms significantly influence human rights, Robert Traer (1998) argued that Human Rights are not merely a matter of law. They cannot entirely be derived from legal precedents of the past, nor empirical evidence or logic, but require a leap of faith. Human rights norms require religious narratives to ground their normative foundations. Contemporary understanding of human rights is a very recent affair. It was developed gradually through western socio-political history and Enlightenment. The medieval religious philosophy of natural law/objective moral order was considered the philosophical 
foundation of modern human rights (Haule, 2006). It was John Locke and other enlightenment thinkers who derived the idea of natural right from natural law.

The natural rights claim of the modern secular right, subjective freedom and liberty of the individual, is founded upon the human dignity and worth that major religions doctrines propagate. In support of this claim, John Witte and Christian Green (2009) asserted that human rights norms have grown in international law out of longstanding religious and cultural traditions that provided a forum and a focus for subtle and sophisticated philosophical, theological, and political reflections on the common good and lives. Religion is believed to invariably provide many sources and 'scales of values' by which many persons and communities govern themselves (Witte, 2001). Major monotheistic religions of the world have often sought to establish a comprehensive moral code, parts of which have been based on a revealed divine law that its adherents must follow.

Religions inevitably help define the meanings and measures of shame and regret, restraint and respect, responsibility, and restitution that the modern human rights regime presupposes (Lauren, 1998). The term 'human rights' as such is not found in traditional religions. Nonetheless, theology presents the basis for a human rights theory stemming from a law higher than that of the state. This law, which is higher than the state, gives rise to shared humanity and the universality of specific rights. Because rights stem from a higher source, they are inalienable by the mortal authority.

Moreover, what makes religion fundamental for human rights is that it contains convictions about human beings' dignity and shares a concern with the duties and obligations individuals have to each other, to nature and the divine. Human dignity serves as the defining status of human beings as subjects of basic respect. Respect for dignity is a central moral guideline of major religions. The modern human rights system also derived the universality of the principles of human rights by incorporating the idea of respect, dignity, and worth of humanity. The respect of the dignity and worth of human beings opened the door for the formation of common standards of human rights universally, as most religions are inherently enriched with the idea of human dignity. Heiner Bielefeld (2012) argued that it is difficult even to begin any severe normative negotiations or embark on any common normative projects under international human rights law unless we respect human beings' dignity by their potential of responsible agency. Respect for dignity constitutes the very precondition for any normative interaction. Donnelly once argued, "we have human rights to those things needed for a life of worth of a human being, needed not for life but a life of dignity" (Donnelly, 2003).

\section{The Human Rights Debate in Islam}

Usually, the concepts of modern human rights are assumed to have developed from western traditions. Indeed, the Western human rights theory is a product of a peculiar set of political, religious, and economic circumstances that have attended the history of Western civilization. In the West, Human rights are widely accepted as individual entitlements that grew from modern European thought on natural law (Ali, 2000). However, there is concert evidence that other cultures and religions have similar percepts in them. Shestack (1998) believes that Islam and other non-western religions have values and principles similar to those in modern human rights.

There is a claim from non-western scholars that the current western dominated modern human rights movements struggle to universalize human rights irrespective of the socio-political and cultural values of non-western societies. Not less than eloquently put by novelist Rudyard Kipling`s the white man burden doctrine, the idea of human rights has been aggressively propagated by the westerners as if other parts of the world are barbarian and have no culture of human 
rights. Scholars like Thomas (2012) and Jack Donnelly (1982) are among those who openly expressed such beliefs. Thomas (2012) argued that human rights were indeed, a western concept. However, the adoption of human rights as a universal concept is a necessary one.

Similarly, Jack Donnelly (1982) boldly argued that most Non-Western cultural and political traditions lack the practice of human rights and the very concept, as a matter of historical fact, the concept of human rights is an artifact of modern western civilization. Such is nothing but examples of western arrogance. To shed light on this, Mawdudi (1976) argued that Scholars in the West usually attribute good things to their society. He claims that the West wants to prove the world would have stepped in ignorance and completely unaware of all these benefits of human rights without the awakening from them. It is also argued that whenever the West faces practical realities and competitions from other civilizations, it prefers reality denial. In this regard, the comment of Donnelly (1982) on Islam is a typical example. He argued that Islam's social and political precepts reflect a vital concern for human good and human dignity, but such notions are not in any way equivalent to a concern for or a recognition of human rights.

Here, it is argued that the western view about the rest of the world, especially the Muslim world, regarding human rights is unbalanced and exaggerated. The western claim that the world got the concept of fundamental human rights from the Magna Carta of Britain is just a manifestation of the failure of the West to recognize the contributions of other civilizations. It is already clear that the Magna Carta itself came into existence many centuries after Islam's advent. Before the Enlightenment, no one knew that the Magna Carta contained the Trial's principles by Jury, Habeas Corpus, and the Control of Parliament on the Right of Taxation (Ali, 2000). Daneshyar (2003) argued that unlike the western world, the Islamic World had a comprehensive system of preservation of man's Fundamental Human Rights 1500 years before the Council of Europe, the United States, or the United Nations ever thought of the concept. Islam guaranteed human rights long before the inception of the modern concept of human rights in Europe. Unlike the modern human rights movement, which is a reaction to mass murders and genocides, Islam proactively attempts to guide humans to attain a higher level of interaction with one another. Rights guaranteed in Islam are the gift from God in exchange for duties imposed on humans.

\section{Confusions and Misconceptions}

There is perceived and actual resistance to the western conception of human rights in the nonwestern world. In the Muslim world, for instance, the resistance is more perceptible. The justification of the rejection was not by the fact that Islam, by its nature, is anti-human rights. Instead, the modern human rights conception is dominated by the Western world's socio-cultural and political dynamics that do not give considerable value to the Islamic culture and civilization. Similar skepticism and resistance are also observed from many Asian and African UN member states, perceiving the rights language and concepts instruments "as manifestations of cultural imperialism and euro-centrism" (Ali, 2000). In the Islamic context, the situation is further aggravated where some aspects of the international human rights law are directly opposite to the central tenet of Islam.

The hypocritical nature of the governments in the Muslim world, who use religion and culture as a scapegoat for their violation of human rights, has also contributed to the existing contradictions. The lack of human rights in the Muslim world and particularly the Arab world stems not from the presence of Islam or the lack of human rights substance in the religion instead from the fact that the governments have abandoned those human rights, the rights enshrined in Sharia law that the citizens expected to enjoy. 
It is preferred here to see the origin of the contestation between Islam and modern secular human rights from two basic wrong beliefs. The first is the cultural chauvinism entrenched among western scholars and politicians who failed to entertain and acknowledge the multiculturalism in the modern human rights regime. This is observed in the drafting process of UDHR. The West made UDHR based on their perception of the world without wondering about the rich cultural verities on the ground. The then Saudi delegate to the committee examining the draft of the declaration made an argument concerning the failure of the UDHR to entertain multiculturalism. The delegate argued the authors of the draft declaration had, for the most part, taking into consideration only the standards recognized by Western civilization and had ignored more ancient civilizations that were past the experimental stage (Ignatief, 2001). Even some western anthropologists openly spoke out about the failure of the UDHR to tolerate the culture and belief system of other societies other than the West. In its statement in 1947 on the draft of UDHR, the American anthropology association asserts that the declaration must be worldwide applicable and must embrace and recognize the validity of many different ways of life (American Anthropological Association, 1947).

The second is the misconception and confusion the West has about Islam. The misconception is associated with the spread of Islam and the behaviors of Muslims. In the West, Islam is often portrayed as a religion spread by the sword and misrepresented Muslims as barbaric and backward, who do not have any human sentiment. This misconception even has led the West, deviating from the principle they propagate as universal, to violate Muslims' human rights. The West is also confused with Muslim governments' and individuals' actions and Islam's principles itself. As all human rights conventions and the principles of UDHR may not be respected by all countries that ratified them, the principles of Islam also may be misused and violated by its adherents, including governments. Totalitarian and corrupt governments have been using Islam as a shield for their gross human rights violations. Meanwhile, the westerners persisted in broadening the gap between their human rights conception with the Muslim world rather than searching for a common understanding to fight for those governments committing gross violations.

The above contradictions forced most Muslims to believe that the West's primary intention is not to work towards the respect of human rights. Instead, there is a hidden agenda behind it. The western approach to the human rights subject is not from the basis of wanting to truly end the suffering of those who are oppressed under Islamic government but as a means of exerting unwarranted political influence and a means of exploiting resource in the oil-rich Arab world hence, denigrate the people and society. The Rights of those who are oppressed only become important when there is a higher political interest to serve. In support of this argument, one can provide the support given for Saddam Hussain by the United States during his gassing of the Kurds of Halabja in 1988 and the invasion of Iraq in 2003 on the pretext of the war on terror only to use the incident as a whip when it suited its interest (Daneshyar, 2003). Besides, their swift military intervention in Libya on a pretext to save the lives of peaceful, pro-democracy protesters targeted by Libyan the then ruler Muammar al-Qaddafi and their hesitation for intervention in Syria and Yemen though there has been a horrific human right violation is taking place, are some examples.

\section{Clearing the Doubts: Human Rights in Islam}

Every society must ensure for its citizens the rights that guarantee their basic needs and security and enable them to feel a sense of belonging and attachment to the larger social group (AlSheha, 2007). Individuals need to feel secure and have a sense of belonging to perform their tasks and duties peacefully and satisfactorily. Islam as a religion and Muslims as societies have 
such normative and religious principles enshrined under the Islamic jurisprudence that guaranteed fundamental rights that enhanced the peace and security of the individuals, families, and groups, respecting human dignity families in general and individuals in particular. Unfortunately, most of the time, because of the above misconceptions and confusion, plus some erratic actions from Muslim governments and extremist groups, Islam has been deemed by many as a sign of oppression and inequality. When western academics, politicians, and NGOs that specialized in the field of human rights discuss the concept of human rights in the Arab and Muslim world, they often attempt to show that the reason for the absence of human rights in the Muslim and Arab world is the presence of Islam (ibid).

The fact, however, is that Islam has an important place for human rights. Mawdudi (1976) argued that Islam has laid down some universal fundamental rights for humanity as a whole, which are to be observed and respected under all circumstances. These fundamental rights are guaranteed for every human being by his status as a human. Likewise, Ishaque (1974) claimed that Muslims are continuously commanded to seek ways to assure each other what modern language is called human rights. The human being in their totality and as a whole have guaranteed rights in Islam. About this, it is mentioned in the Qur'an (17:70) that "God has conferred "dignity" on the children of Adam, whatever their innate and acquired differences maybe." From this Quranic view, the human being is not supposed merely to survive but to enjoy the dignity and good life conferred on it by God.

Furthermore, the most critical human rights declaration in the Muslim world based on sharia demonstrated the centrality of Islam's human rights. The Universal Islamic Declaration of Human Rights (UIDHR), prepared by Eminent scholars, Muslim jurists, and representatives of movements of Islamic thought at a UNESCO meeting of 19 September 1981, pronounced the normative base of human rights under Islam as follows:

Islam gave humanity an ideal code of human rights 1400 years ago. The purpose of these rights is to confer honor on humanity and to eliminate exploitation, oppression, and injustice. Human rights in Islam are deeply rooted in the conviction that God, and God alone, is the author of law and the source of all human rights. Given this divine origin, no leader, no government, no assembly, or any other authority can restrict, abrogate, or violate in any manner the rights conferred by God. (Arkoun, 1994)

Another essential document is the Cairo Declaration of Human Rights in Islam (the Cairo Declaration) issued by the 19th Conference of Foreign Ministers adopted by the member states of the Organisation of the Islamic Conference in 1990. The declaration has contained important basic human rights principles. It was proposed to reaffirm the civilizing and historical role of Islamic society in which God made the best nation that has given humankind a universal and well-balanced civilization in which harmony is established between itself and the hereafter (The Cairo declaration, 1990). It was also from the positive wish to contribute to the effort of humankind to assert human rights to protect man from exploitation and prosecution by affirming his freedom and right to a dignified life under Islamic law.

\section{Foundations of Human Rights in Islam}

In Islam, there are fundamental sources where human rights are founded. The Islamic jurisprudence recognizes the Qur'an and Hadith as a fundamental source of law. The most important one is the Qur'an, which is believed by Muslims to be the word of God and is regarded as the primary and most authoritative source of normative law in Islam. The Qur'an is the Magna Carta of human rights, and most of its concern is to free human beings from the bondage of traditionalism, authoritarianism (Hassan, 2009). The hadith, a brief saying about what prophet Mohammed did or said, is also considered as guiding principles for Muslims. These are the collections made from different companions of the prophets who recorded and preserved it and passed 
through generations starting from the first chain of narrators to the last who recorded it. In addition to the Qur'an and the hadith, which are the fundamental source of law, there are other sources accepted as secondary sources; these include, Ijma, Qiyas, and Ijtihad. Ijma or consensus stands for the idea when there are a unanimous agreement and decision on something by qualified Muslim scholars (Julia, and Omar, 2017). This is an essential principle the Muslim community is expected to act on when they left to solve the critical judicial problems that are not openly addressed by the Qur'an or hadith. Qiyas is the process of analogical reasoning and comes into operation in matters which have not been covered by a text of the Qur'an or the hadith, nor determined by the consensus of Muslim scholars (Ali, 2000). Last but not least is ijtihad, which means exercising independent juristic reasoning to provide answers when the Qur'an and Sunnah are silent on a particular subject (Ramadan, 2006 and Ali, 2000).

According to Islamic jurisprudence, human rights, which are termed as Huqooq-ul-Ibaad in Arabic, are the duties humans owe to fellow human beings, such as abstaining from causing harm to the life, property, and honor of other humans (Khilji, 2011). Islam affirmed that fundamental rights are possessed by all humans only because they are so deeply rooted in humanness; subsequently, their denial or violation is tantamount. It asserts that they should be observed and respected under all circumstances whether such a person is resident within the territory of the Islamic state or outside it, whether he is at peace or war (Hassan, 2009). Human rights are the gift of God and are free of the deed of the human. Hence, they cannot be abolished by any earthly power. Therefore, it is an individual, social, and universal responsibility of Muslims to respect, protect, and fulfill the human rights of all humans. In support of this conclusion, the glorious Qur'an clearly stated: "O believers, stand up firmly by the Commandments of Allah, bearing witness with justice, and let not the enmity of any people incite you that you should not do justice. Do justice that is nearer to piety and fear Allah, undoubtedly, Allah is aware of your doings" (Al- Qur'an 5, 8).

\section{Fundamental Human Rights in Islam}

Human rights are specified in Islam as the Maqâsid Al-Sharî'ah, the goals and objectives of Islamic law. Maqâsid al-Sharî'ah was developed by Muslim jurists and scholars of the science of Islamic Jurisprudence as a system of higher objectives corresponding to the purposes and aims of Islam. It is predicated on the benefits of the individual and that of the community, and its laws are designed to protect these benefits and facilitate improvement and perfection of the conditions of human life on earth (Kamali, 1999). There are five fundamental elements of human life preserved by Maqâsid al-Sharî'ah that are: ad-din (religion), An-Nafs (life), Al-`Aql (intellect), An-Nasl (ancestry) Andal-Mal (property or wealth) (Abdullah, 2015).

There are several fundamental principles of human rights derived from the above central aims of the religion of Islam. The most basic and crucial, as it is universal, is the right to life. Numbers of Qur'anic verses put the sanctity of human life and the seriousness of its violation. In Islam, human blood is sacred in any case and cannot be spilled without any justification. If anyone takes a soul without justification, it is considered as the killing of the entire humankind.

Regarding this, the Qur'an says: “...whosoever killed a person - unless it is for killing a person or for creating disorder in the land - it shall be as if he had killed all mankind, and whoso gave life to one, it shall be as if he had given life to all mankind" (Al-Qur'an 5,32). The Cairo declaration of human rights in Islam reaffirmed the idea in article 2 by saying; Life is a Godgiven gift, and the right to life is guaranteed to every human being. It is the duty of individuals, societies, and states to protect these rights from any violation, and it is prohibited to take away life except a sharia prescribed reason. 
Another important right recognized in Islam is the right to equality. It is an essential and significant principle in Islam. It is anchored in Islam`s core that men and women are created equal in their basic humanity, and all have the shared lineage and dignity of Allah's creation and privilege of man over the other creatures of his creation (Al-Sheha, 2007). Discrimination in race, sex, color, lineage, class, religion, or language is strongly prohibited in Islam. Such diversities are nothing but the beauty of creation or else to know each other as it is mentioned in AlQur'an (49.13). It says, "O mankind, we have created you from a male and female, and we set you up as nations and tribes so that you may be able to recognize each other." The Cairo declaration also stated that all humanity is equal in terms of basic human dignity and primary obligation and responsibility, without any discrimination based on other considerations (The Cairo declaration, 1990, Art.1).

The right to justice and freedom are also notable rights recognized in Islam. Muslims are expected to be just for people, even if they are enemies. The Qur'an has laid down: "Do not let your hatred of a people incite you to aggression" (Al- Qur'an 5,2). Moreover, "do not let ill-will towards any folk incite you so that you swerve from dealing justly. Be just; that is nearest to heedfulness" (Al- Qur'an 5,8). The personal freedom for a Muslim lies in the Quranic ruling that no one but God limits human freedom. The Qur'an says Judgment as to what is right and what is wrong rests with God alone (Al-Qur'an 6:57). Islam also recognizes the right to religious freedom in the case of other believers in God and non-believers in God so far as they are not aggressing upon Muslims (Al-Sheha, 2007).

Regarding religious freedom, the most crucial verse in the Qur'an is "There should be no compulsion in religion. Surely, the right has become distinct from wrong" (Al- Qur'an 2. 256). In addition to these rights, numerous rights are recognized and protected by sharia. Security of Personal Freedom, the right to Sustenance/property; the Right to Work; the Right to Privacy; and the right to protest against tyranny are other vital rights guaranteed in Islamic laws (Mawdudi, 1976).

It is not being claimed here in any manner that there is no contradiction between the western and Islamic conception of human rights. There are apparent contradictions, especially about rights the west advocate as universal but considered abhorrent in Islam. Apart from this, Islam has recognized the most basic human rights that are universally accepted. Muslims and nonMuslims under Islamic rule had been enjoying those rights for many centuries. The legitimacy of the Islamic state is dependent on the implementation of Islamic rules unquestionably. As a part of the overall rule of law, the rights of the individual enjoyed total respect and protection.

\section{Conclusion}

The languages and substances of modern human rights movements have been shaped by major social-political dynamics that occurred in Western Europe and America. The glorious revolution, the American war of independence, and the French revolution have contributed a lot to the growth of modern human rights movements. However, its failure to consider the cultural variations worldwide has resulted in resistance from different cultural and religious groups. Bridging the gap between the western and non-western conceptions of human rights is necessary as most of their principles reinforce each other than contrast. For this, there have to be open dialogs and mutual understanding. Islam, as a religion, has a significant contribution to the respect and protection of human rights. International human rights movements should deeply study the religion and start to consolidate its principles to get legitimacy among Muslim societies. Scholars are also expected to fill the knowledge gap that existed in this regard with deep sincerity and professional honesty. In-depth and extended research and study have to be conducted before any cultural and religious practice are deemed a violation of human rights and dignity. 


\section{References}

Abdullah, S. (2015). The Objectives Of Takaful And Shariah: Towards The Achievement Of Maqasid Shariah. Vol. 8 No. 1, pp. 93-104.

Ali, S. Sardar. (2000). “Gender and Human Rights” in Islam and International Law: Equal Before Allah, Unequal Before Man? Kluwer Law International, The Hague.

Al-Sheha, Abdul-Rahman (2010). Human Rights in Islam and Common Misconceptions. Ideas4islam, Riyadh, Saudi Arabia.

American Anthropological Association. ( 1947). The Executive Board Statement On Human Rights. American Anthropologist, New Series, Vol. 49, No. 4, Part 1, pp.539-543.

Arkoun, M. (1994) "Human Rights" in M. Arkoun, Rethinking Islam Common Questions, Uncommon Answers, Boulder, CO: West view Press.

Bielefeldt, Heiner(2012). Freedom of Religion or Belief-A Human Right under Pressure. Oxford Journal of Law and Religion, Oxford University Press, pp. 1-21.

Connelly, Paul. (1996). Definition of Religion and Related Terms. Available online at http://www.darc.org/connelly/religion1.html.

Daneshyar, Osama (2003) fundamental human rights in Islamic sharia law. online: www.ihrc.org.uk/attachments/7173_ossierepFINAL.pdf.

Donnelly, Jack (1982) Human Rights and Human Dignity: An Analytic Critique of Non-Western Conceptions of Human Rights. American Political Science Association, The American Political Science Review, Vol. 76, No. 2, pp. 303-316.

Donnelly, Jack(2003). Universal Human Rights In Theory And Practice, 2nd edition, Cornell University Press.

Grant, Evadné. (2007). Dignity and Equality. Human Rights Law Review, Volume 7, Issue 2, 1 January 2007, pp. 299-329.

Gunn, T. Jeremy. (2003). The Complexity of Religion and The Definition of' Religion” In International Law, Harvard human rights journal, vol.16, pp.190-215.

Hassan, Riffat, (2009) Are Human Rights Compatible with Islam? The Issue of the Rights of Women in Muslim Communities, University of Louisville, Louisville, Kentucky.

Ignatief, Michael. (2001) The Attack on Human Rights. Foreign Affairs, vol.80, No.6, pp.102-116.

Ishaque, M. Khalid (1974). Human rights in Islamic law. Review of the International Commission of Jurists 12:30-9.

Jozwiak, Jeffrey L. (2008) The Significance of Religion on Health Factors Related to Aging Among American Adults Using the National Survey of Midlife Development in the United States. Doctoral Dissertation, University of Pittsburgh. (Unpublished).

Julia, Taslima, and Omar, B. Zainab. (2017). Application of Ijma' in Modern Islamic Finance Rulings: Does Ijma' Really Exist? A literature review. Bangladesh Journal of Islamic Thought, 13(19).

Khilji, A. (2011). Islamic Concept of Human Rights vs Western Concept - CSS Forums. Retrieved 06 October, 2018, from http://www.cssforum.com.pk/css-compulsory-subjects/islamiat/islamiat-notes/59400-islamic-concepthuman-rights-vs-western-concept.html.

Lauren, P. Gordon. (1998). The Evolution of International Human Rights: Visions Seen. Philadelphia: University of Pennsylvania Press.

Mawdudi, Abul A'la. (1976). Human rights in Islam. Leicester: The Islamic Foundation.

Organization of the Islamic Conference. (1990). Cairo Declaration on Human Rights in Islam. available at: http://www.refworld.org/docid/3ae6b3822c.html [accessed 1 October 2018].

Ramadan, H. M. (2006). Understanding Islamic law: From classical to contemporary. Lanham, MD: Rowman \& Littlefield.

Random House. (1987). The Random House Dictionary of the English Language. (ed) Stuart Berg Flexner. 2nd ed. New York.

Shestack, J. (1998). The Philosophic Foundations of Human Rights. Human Rights Quarterly, 20(2), 201-234.

The Glorious Qur'an English translation by Kanzul Iman and Maulvi Sher Ali.

Thomas, NG. (2012). Are Human Rights a Western constructed? From the Confucius peace prize to the practice of suttee in India, The Journal of International Social Research, Volume: 5 Issue 21.

Tillich, Paul (1963). Christianity and the Encounter with World Religions, New York, Columbia UP. 
Traer, Robert(1998). Faith in Human Rights in Church \& Society, Presbyterian Church, U.S.A, pp. 46-58.

Witte, John, and Green, Christian. (2009). Religious Freedom, Democracy and International Human Rights, Emory International Law Review, Vol. 23, pp. 503-608.

Witte, Jr. John. (2001). A Dickensian Era of Religious Rights: An Update on Religious Human Rights in Global Perspective. 42 Wm. \& Mary L. Rev. 707. 